\title{
Evaluation of the toxicity and antiulcerogenic activity of the ethanol extract of Maytenus obtusifolia Mart. leaves
}

\author{
Kelly Samara de Lira Mota, João Carlos Lima Rodrigues Pita, Ethiene Castellucci Estevam, \\ Viviane Marcelino Medeiros, Josean Fechine Tavares, Maria de Fátima Agra, Margareth de \\ Fátima Formiga Melo Diniz, Marcelo Sobral da Silva, Leônia Maria Batista*
}

Laboratório de Tecnologia Farmacêutica "Prof. Delby Fernandes de Medeiros", Departamento de Ciências

\begin{abstract}
RESUMO: "Avaliação da toxicidade e atividade antiulcerogênica do extrato etanólico das folhas de Maytenus obtusifolia Mart." Maytenus obtusifolia é utilizada na medicina popular para o tratamento de úlceras graves, inflamações gerais e câncer. Apesar da importância etnofarmacológica desta espécie, nenhum estudo foi realizado para avaliar a sua toxicidade e atividade antiulcerogênica. Neste estudo, nós avaliamos a toxicidade e propriedade antiulcera do extrato etanólico das folhas de Maytenus obtusifolia (MO-EtOH). O MO-EtOH $(10-1000 \mu \mathrm{g} / \mathrm{mL})$ mostrou baixa toxicidade para as larvas de $A$. salina com $\mathrm{CL}_{50}$ maior que $1000 \mu \mathrm{g} / \mathrm{mL}$. O MOEtOH (2000 mg/kg, p.o.) não alterou o peso corporal e peso dos órgãos dos camundongos, mas foi observado um aumento no consumo de água dos machos e uma diminuição do consumo alimentar das fêmeas. Durante o estudo não foram observadas mortes e nem alterações macroscópicas nos órgãos dos camundongos. MO-EtOH $(62,5,125,250$ e $500 \mathrm{mg} / \mathrm{kg})$ e lansoprazol $(30 \mathrm{mg} / \mathrm{kg})$ reduziram significativamente o índice ulcerativo para $65,58 \pm 8,74,43,00 \pm 9,53,15,50 \pm 7,56$, $54,75 \pm 8,88$ e $36,13 \pm 9,55$, respectivamente, em comparação com salina $82,13 \pm 12,48$. Em conclusão, o MO-EtOH apresentou baixa toxicidade e atividade antiulcerogênica, o que confirma o uso popular de M. obtusifolia.
\end{abstract}

Unitermos: Maytenus obtusifolia, Celastraceae, Artemia salina, toxicidade aguda oral, atividade antiulcerogênica.

\begin{abstract}
Maytenus obtusifolia is used in folk medicine for the treatment of serious ulcers, general inflammations and cancer. Despite of the ethnopharmacological importance of this species, no study was conducted to evaluate its toxicity and antiulcerogenic activity. In this study, we evaluated the toxicity and antiulcerogenic property of the ethanol extract of the leaves of Maytenus obtusifolia (MO-EtOH). The MO-EtOH $(10-1000 \mu \mathrm{g} / \mathrm{mL})$ showed low toxicity for larvae of $A$. salina with $\mathrm{LC}_{50}$ higher than $1000 \mu \mathrm{g} / \mathrm{mL}$. The MO-EtOH $(2000 \mathrm{mg} / \mathrm{kg}$, p.o.) did not change the body and organs weight of the mice, but it was observed an increase in the water consumption of males and a decrease in the food consumption of females. During the study no deaths and no macroscopic changes in the organs were observed in the mice. MO-EtOH (62.5, $125,250$ and $500 \mathrm{mg} / \mathrm{kg})$ and lansoprazole $(30 \mathrm{mg} / \mathrm{kg})$ significantly reduced the ulcerative index for $65.58 \pm 8.74,43.00 \pm 9.53,15.50 \pm 7.56,54.75 \pm 8.88$ and $36.13 \pm 9.55$, respectively, in comparison with saline $82.13 \pm 12.48$. In conclusion, the MO-EtOH showed low toxicity and antiulcerogenic activity, confirming the popular use of M. obtusifolia.
\end{abstract}

Keywords: Maytenus obtusifolia, Celastraceae, Artemia salina, acute oral toxicity, antiulcerogenic activity.

\section{INTRODUCTION}

The plants have acquired crucial importance in folk medicine, because of its therapeutic or toxic properties (Martins et al., 2003). The use of vegetal extracts in the treatment of some diseases is a widespread habit in Brazil. This habit may be explained, at least in part, by the belief that the plants exhibit therapeutic effect without causing toxic effects in the organism. Therefore, the search of medicinal plants has great scientific importance, because it intends to validate the popular use and give greater safety (Brandão et al., 2006; Carvalho et al., 2008; Veiga-Junior et al., 2008).

In this context, a prominent family is Celastraceae, a large family of trees and shrubs. It is comprised by approximately 89 genera and 1300 species, with Maytenus as one of the largest genera, with some 270 species distributed throughout Brazilian territory (Stevens, 2001). Plants of this genus are used in South America's folk medicine like infusion or decoctions, due 
to their analgesic, anti-inflammatory and antiulcerogenic activities (Côrrea, 1984; Bueno et al., 2005).

Several species of Maytenus have theirbiological activities proven experimentally. Maytenus ilicifolia one of the most studied species showed antinociceptive, anti-inflammatory (Jorge et al., 2004), antioxidant (Vellosa et al., 2006; Melo et al., 2001) and antiulcer activities (Jorge et al., 2004). Antimicrobial (Kloucek et al., 2007) and antileishmanial activities (PerezVictoria et al., 1999) were found in M. macrocarpa. It has also been demonstrated antimutagenic, antioxidant and antimicrobial properties of $M$. krukovii (Bruni et al., 2006) as well as inhibitory activity of the DNA polymerase $\beta$-lyase of $M$. putterlickoides (Feng et al., 2004). It was also documented an analgesic property for M. aquifolium (Gonzáles et al., 2001) as well as antiulcerogenic activity of $M$. robusta (Andrade et al., 2007). M. senegalensis revealed antiplasmodial (Gessler et al., 1995; El Tahir et al., 1999), antibacterial (Matu \& van Staden, 2003), antiviral activities (Otake et al., 1995) and antitumor property (Gessler et al., 1995).

In recent pharmacological studies our group showed that the ethanol extract of Maytenus rigida Mart. in the doses of 250,500 and $750 \mathrm{mg} / \mathrm{kg}$ possesses antiinflammatory, antiulcer and anti-diarrehoeal activities (Santos et al., 2007).

M. obtusifolia is distributed in many states of the Northeast and Southeast of Brazil. It is popularly known as "carne-de-anta", "carrancudo" or "bom-nome" and used in folk medicine like decoction from leaves for the treatment of serious ulcers (Corrêa, 1984), general inflammations and cancer (Agra et al., 2007). Grounded as powder from Stem-bark, it is used against external ulcers on the skin (Agra et al., 2007). The phytochemical screening showed the occurrence of three different chemical classes of secondary metabolites in $M$. obtusifolia, alkaloids for example $N$-methylflindersine, pentacyclic triterpenes as 3,4-secofriedelan-3-oic acid, 3b-hydroxy-11, 13-en-oleanane, 7-oxofriedelin, 3-oxo29-hydroxyfriedelan, friedelin, 3b-hydroxy-9, 12-enoleanane and 3b-hydroxy-9,12-en-ursane and flavonoids of the type 4'-O-methyl-(-)-epigallocatechin, ourateaproanthocyanidin A, catechin and epicatechin (Silva et al., 2008). Pharmacological studies demonstrated that this species possess analgesic (Freire, 1998) and neuroleptic activities (De Sousa \& De Almeida, 2005).

Despite the popular use of this species, few pharmacological studies have been described in literature and there are no data on the toxicity of extracts of the leaves and their pharmacological effect on the gastric ulcer. Thus, the interest in this plant is justified by its potential medicinal value. Therefore, the aim of this study is to investigate the toxicity and antiulcerogenic activities of the ethanol extract obtained from the leaves of M. obtusifolia.

\section{MATERIAL AND METHODS}

\section{Plant material and ethanol extract preparation}

M. obtusifolia was collected in February, 2005, in Santa Rita, Paraíba, Brazil. It was identified by Dr. Maria de Fátima Agra, botanist from "Laboratório de Tecnologia Farmacêutica Prof. Delby Fernandes de Medeiros (LTF)/Universidade Federal da Paraíba (UFPB)" and a voucher specimen (Agra 3230) was deposited in the Herbarium Lauro Pires Xavier of the Department of Botany - UFPB, João Pessoa, Brazil. The leaves of $M$. obtusifolia were dried in oven at $45{ }^{\circ} \mathrm{C}$ for 3 to 4 days. After drying, the leaves $(3,453.6 \mathrm{~g})$ were powered and macerated with $95 \%$ ethanol $(\mathrm{EtOH})$ in three process of extraction, in intervals of 72 hours. The macerated leaves were filtered and concentrated under reduced pressure/rotaevaporator at $50{ }^{\circ} \mathrm{C}$, resulting in the crude ethanol extract weighing $815.7 \mathrm{~g}(23.62 \%$ on dry weight of the plant).

\section{Animals}

Male Swiss mice (28-35 g) were used to do in vivo experiments. They were obtained from the Biotery Thomas George of the LTF/UFPB. The animals were maintained in light/dark cycles of $12 \mathrm{~h}$ at $60 \pm 1 \%$ of humidity and temperature of $21.5 \pm 2{ }^{\circ} \mathrm{C}$, with food and water ad libitum. The experimental protocols were approved by the Institutional Committee of Ethics in Animal Research of the LTF/UFPB, registered under 0205/07.

\section{Brine shrimp lethality test}

To evaluate the toxicity of MO-EtOH, it was used the brine shrimp (A. salina) lethality test. $25 \mathrm{mg}$ of eggs of $A$. salina were incubated in sea water ( $\mathrm{pH} 8-9$ and $29{ }^{\circ} \mathrm{C}$ ) at artificial light during $24 \mathrm{~h}$ for occlusion of cysts and obtaining of the larvae. The extract was diluted in sea water $(10-1000 \mu \mathrm{g} / \mathrm{mL})$ and then it was added 5 $\mathrm{mL}$ of different concentrations of MO-EtOH in tubes containing 13 to 15 nauplii. Three replications were done for each concentration and the experiment was repeated three times. The control group was prepared with the solvent and $A$. salina. The set was incubated at artificial light for $24 \mathrm{~h}$ and then the survivors larvae were counted to determine the $\mathrm{LC}_{50}$ (Lopes et al., 2002; Parra et al., 2001).

\section{Evaluation of the acute oral toxicity}

The acute oral toxicity study of $M$. obtusifolia was performed in mice. In this assay a single dose of $2000 \mathrm{mg} / \mathrm{kg}$ of MO-EtOH was orally administered $(1 \mathrm{~mL} / 100 \mathrm{~g})$ to a group of twelve animals (six male and six female) after $6 \mathrm{~h}$ fast. Animals receiving the vehicle (saline solution $0.9 \%$ ) served as control. After treatment the behaviour parameters were observed, like 
stimulatory, depressor effects and the death, during 30 , $60,90,120,180$ and 240 minutes in the first day and once daily in the following 13 days to assess possible clinical or toxicological symptoms (Almeida et al., 1999). The body and organs weight, food and water consumption were evaluated in both sexes. At the end of the period of 14 days, the number of survivors was recorded for the determination of the $\mathrm{LD}_{50}$. Macroscopic changes in the organs of the mice were evaluated.

\section{$\mathrm{HCl} /$ ethanol-induced gastric lesions}

The experimental was performed according to Mizui \& Doteuchi (1981). After $24 \mathrm{~h}$ fasting, the mice $(\mathrm{n}=6-8)$ received an oral administration of MO-EtOH at the respective doses of $62.5,125,250$ and $500 \mathrm{mg} /$ $\mathrm{kg}$ and positive control (lansoprazole, $30 \mathrm{mg} / \mathrm{kg}$ ) or negative control (saline $0,9 \%, 10 \mathrm{~mL} / \mathrm{kg}$ ). Fifty minutes after the treatment, all mice received $0.2 \mathrm{~mL}$ of $0.3 \mathrm{M}$ $\mathrm{HCl} /$ ethanol $60 \%$ to induce gastric ulcer. The animals were killed $1 \mathrm{~h}$ after treatment with the ulcerogenic agent and the stomachs were removed and opened along the grater curvature. The ulcerative index (UI) was calculated according to the methodology described by Szelenyi \& Thiemer (1978).

\section{Statistical analysis}

The results are expressed in mean \pm S.D. Differences between the means were statistically compared using Student's t-test for acute toxicity and one-way analysis of variance (ANOVA) followed by Dunnett's test for the antiulcerogenic activity. The values

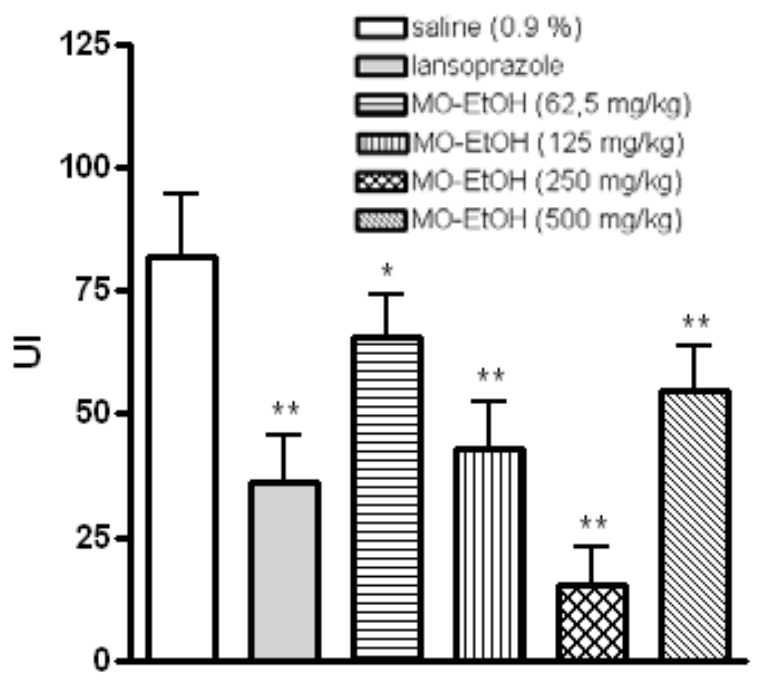

Figure 1. Effect of the ethanol extract obtained from $M$. obtusifolia on UI. The results are expressed as mean \pm SD for six or eight mice. Statistical comparison was performed using ANOVA followed by the Dunnet's test. ${ }^{*} p<0.05$ and ${ }^{* *} p<$ 0.01 in comparison with saline $0.9 \%$. were considered significantly different when the levels of $p<0.05$. The software used was the GraphPad Prism ${ }^{\odot}$ 4.03 software (GraphPad Software Inc., San Diego CA). The $\mathrm{LC}_{50}$ for brine shrimp lethality test was determined according to the statistical method of Probitos using the program Microcal Origin 6.0.

\section{RESULTS AND DISCUSSION}

M. obtusifolia is used in folk medicine for the treatment of serious ulcers (Corrêa, 1984), general inflammations, cancer (Agra et al., 2007) and against external ulcers on the skin (Agra et al., 2007). However, very little is known about their toxicity. For this reason, research is carried out in order to determine the pharmacological action and toxicity of this plant (Parra et al., 2001).

In the present study, the toxicity of the MOEtOH by the brine shrimp lethality test was examined. This bioassay was performed three times and the $\mathrm{LC}_{50}$ of these three tests were higher than $1000 \mu \mathrm{g} / \mathrm{mL}$ (Data not shown). Thus, the MO-EtOH showed low toxicity for larvae of $A$. salina.

Additionally, we evaluated the acute oral toxicity of the ethanol extract and we observed that the single dose of $2000 \mathrm{mg} / \mathrm{kg}$ of the MO-EtOH induced analgesia in the second and third hours after oral administration in the mice after administration, this effect was reversible in the fourth hour after treatment. This result is consistent with those obtained for Freire (1998), in which M. obtusifolia showed analgesic activity. During the 14 days of observation no deaths were showed and at the end of the experiment no macroscopic changes in the organs were observed in the animals.

In addition to these parameters, the evolution body weight was evaluated, in which changes are an indicator of adverse side effects, as the animals that survive cannot lose more than $10 \%$ of the initial body weight (Raza et al., 2002; Teo et al., 2002). The water and food consumption were also evaluated, which are important parameters in the study of safety of a product with therapeutic purpose (Iversen \& Nicolaysen, 2003).

In the present work, MO-EtOH did not induce changes in the body and organs weight of the mice of both sexes, water consumption of the females and food consumption of the males when compared with their respective control group (Table 1). But an increase in water consumption of the male mice treated with the extract was observed (Table 1). This result may be related with an increase in the diuresis, which leads to much urinary volume and consequently more water consumption. A decrease in food consumption of the females was showed (Table 1) without, however, changing the weight of the mice when compared with the saline group. This finding may be due to a decrease in the metabolism of the females. These results suggest that the ethanol extract obtained from the leaves of the 
M. obtusifolia shown low toxicity to mice treated orally in the tested dose, thus ensuring safety for the research of the antiulcerogenic activity, with intention to prove the traditional use of this plant.

Peptic ulcer is a common disorder of the entire gastrointestinal tract (Maity et al., 2003). It occurs mainly in the proximal duodenum and stomach. When located, this is called gastric ulcer, which are deep necrotic lesions involving the entire mucosal depth and the muscularis mucosae (Chow et al., 1998; Tarnawski, 2005). Gastric ulcer has been centralized on an imbalance between some endogenous and exogenous aggressive (hydrochloric acid, reactive oxygen species, ethanol, Helicobacter pylori, steroidal and nonsteroidal antiinflammatory drugs, among others) and defensive factors (mucus-bicarbonate barrier, surface active phospholipid, prostaglandin, mucosal blood flow, cell renewal and migration, antioxidants and antioxidative enzymes and some growth factors) (Bandyopadhyay, 2001; Bhattacharjee et al., 2002; Liu \& Crawford, 2005).

The antiulcerogenic activity was evaluated through oral administration of $\mathrm{HCl} /$ ethanol in mice, which causes necrotizing lesions in the gastric mucosa. These lesions are caused by decrease of mucous layer and the increase of acid secretion (Mizui \& Doutechi, 1981). These factors occur because that agent causes oxidative stress and lipid peroxidation and DNA fragmation, resulting in ulcerative lesions (Gonzales et al., 2001). This model evaluates the capacity of the drugs to protect the gastric mucosa, making this technique suitable for investigation of natural products antiulcer activity.

In the present study the $\mathrm{HCl} /$ ethanol solution induced both long ulcers and petechial lesions within a relatively short time, with UI of the saline $0.9 \%$ group of $82.3 \pm 12.48$. Pretreatment with MO-EtOH

Table 1. Effect of the ethanol extract obtained from M. obtusifolia $(2000 \mathrm{mg} / \mathrm{kg}$, p.o.) on body and organ weights and water and food consumption in mice.

\begin{tabular}{|c|c|c|}
\hline & Control (saline $0.9 \%$ ) & MO-EtOH $(2000 \mathrm{mg} / \mathrm{kg})$ \\
\hline \multicolumn{3}{|l|}{ Body weight (g) } \\
\hline Initial & $34.08 \pm 2.91$ & $32.22 \pm 4.14$ \\
\hline Final & $37.88 \pm 3.92$ & $35.32 \pm 3.84$ \\
\hline Increased $(\%)$ & $09.48 \pm 5.21$ & $08.91 \pm 2.96$ \\
\hline \multicolumn{3}{|l|}{ Male } \\
\hline Initial (g) & $35.92 \pm 1.66$ & $33.98 \pm 1.91$ \\
\hline Final $(\mathrm{g})$ & $40.90 \pm 2.89$ & $38.78 \pm 2.58$ \\
\hline Increased $(\%)$ & $11.99 \pm 4.22$ & $12.25 \pm 4.28$ \\
\hline \multicolumn{3}{|l|}{ Organ weight (g) } \\
\hline Heart & $0.16 \pm 0.02$ & $0.16 \pm 0.04$ \\
\hline Liver & $1.81 \pm 0.32$ & $1.74 \pm 0.36$ \\
\hline Kidney & $0.51 \pm 0.10$ & $0.48 \pm 0.06$ \\
\hline \multicolumn{3}{|l|}{ Male } \\
\hline Heart & $0.19 \pm 0.01$ & $0.18 \pm 0.01$ \\
\hline Liver & $2.31 \pm 0.21$ & $2.18 \pm 0.28$ \\
\hline Kidney & $0.53 \pm 0.04$ & $0.50 \pm 0.05$ \\
\hline \multicolumn{3}{|c|}{ Water consumption (g) } \\
\hline Female & $12.30 \pm 1.84$ & $12.24 \pm 2.00$ \\
\hline Male & $09.74 \pm 0.86$ & $10.62 \pm 1.04^{*}$ \\
\hline \multicolumn{3}{|c|}{ Food consumption (g) } \\
\hline Female & $08.33 \pm 0.91$ & $07.09 \pm 1.26^{* *}$ \\
\hline Male & $06.61 \pm 0.96$ & $06.52 \pm 0.82$ \\
\hline
\end{tabular}

Data are expressed as mean \pm S.D. for six mice. Statistical comparison between saline $0.9 \%$ and MO-EtOH $2000 \mathrm{mg} / \mathrm{kg}$ was performed using Student t-test. ${ }^{*} p<0.05$ and ${ }^{* *} p<0.01$ in comparison with the saline $0.9 \%$. 
$(62.5,125,250$ and $500 \mathrm{mg} / \mathrm{kg})$ and lansoprazole $(30$ $\mathrm{mg} / \mathrm{kg}$ ), significantly reduced the UI for $65.58 \pm 8.74$, $43.00 \pm 9.53,15.50 \pm 7.56,54.75 \pm 8.88$ and $36.13 \pm$ 9.55 , respectively, when compared with the saline $0.9 \%$ group. The MO-EtOH induced a significant protective effect in variable degrees (Figure 1). This result indicates that the plant in study has antiulcerogenic activity. It is consistent with those obtained by Santos et al., (2007), in which the ethanol extract of M. rigida $(125,250,500$ and $750 \mathrm{mg} / \mathrm{kg}$ ) showed antiulcer activity against gastric lesions induced by ethanol in rats. It was also similar to the results observed in the studies undertaken with other species of Maytenus.

\section{CONCLUSION}

The results of this study suggest that the ethanol extract obtained from the leaves of $M$. obtusifolia show low toxicity to both $A$. salina and mice. The MO-EtOH displays gastroprotective activity, as demonstrated by its significant inhibition of the formation of ulcers induced using the $\mathrm{HCl} /$ ethanol model; however, more specific studies must be carried out to elucidate the mechanisms involved in this activity. The data obtained confirmed the popular use of this plant.

\section{ACKNOWLEDGMENTS}

The authors would like to express their sincere thanks to Ms. Gabriela G. Barbosa for the revision of the English grammar and Mr. José Crispim Duarte for providing technical assistance and to CAPES/CNPq for the financial support.

\section{REFERÊNCES}

Agra MF, França PF, Barbosa-Filho JM 2007. Synopsis of the plants known as medicinal and poisonous in Northeast of Brazil. Rev Bras Farmacogn 17: 114140.

Almeida RN, Falcão ACGM, Diniz RST, Quintans-Júnior LJ, Polari RM, Barbosa-Filho JM, Agra MF, Duarte JC, Ferreira CD, Antoniolli AR, Araújo CC 1999. Metodologia para avaliação de plantas com atividade no Sistema Nervoso Central e alguns dados experimentais. Rev Bras Farm 80: 72-76.

Andrade SF, Lemos M, Comunello E, Noldin VF, Cechinel-Filho V, Niero R 2007. Evaluation of the antiulcerogenic activity of Maytenus robusta (Celastraceae) in different experimental ulcer models. J. Ethnopharmacol 113: 252-257.

Bandyopadhyay D, Biswas K, Bhattacharyya M, Reiter RJ, Banerjee RK 2001. Gastric toxicity and mucosal ulceration induced by oxygen-derived reactive species: protection by melatonin. Curr Mol Med 1: 501-513.

Bhattacharjee M, Bhattacharjee S, Gupta A, Banerjee RK 2002. Critical role of an endogenous gastric peroxidase in controlling oxidative damage in $\mathrm{H}$. pylori-mediated and non-mediated gastric ulcer. Free Radical Bio Med 32: 731-743.

Brandão MGL, Cosenza GP, Moreira RA, Monte-Mor RLM 2006. Medicinal plants and other botanical products from the Brazilian Official Pharmacopoeia. Rev Bras Farmacogn 16: 408-420.

Bruni R, Rossi D, Muzzoli M, Romagnoli C, Paganetto G, Besco E, Choquecillo F, Peralta K, Lora WS, Sacchetti G 2006. Antimutagenic, antioxidant and antimicrobial properties of Maytenus krukovii bark. Fitoterapia 77: 538-545.

Bueno NR, Castilho RO, Costa RB, Pott A, Pott JV, Sheidt GN, Silva-Batista M 2005. Medicinal plants used by Kaiowá and Guaranti indegenous populations in the Caarapó Reserve. Mato Grosso do Sul, Brazil. Acta Bot Bras 19: 39-44.

Carvalho ACB, Balbino EE, Maciel A, Perfeito JPS 2008. Situação do registro de medicamentos fitoterápicos no Brasil. Rev Bras Farmacogn 18: 314-319.

Chow JYC, Ma L, Cho CH 1998. The role of adhesion molecules in gastric ulcer healing. WJG 4: 467-468.

Corrêa MP 1984. Dicionário das Plantas Úteis do Brasil e das Exóticas Cultivadas. IBDF-Ministério da Agricultura. Rio de Janeiro 6: 149.

De Sousa DP, de Almeida RN 2005. Neuroleptic-like properties of the chloroform extract of Maytenus obtusifolia Mart. roots. Biol Pharm Bull 28: 224-225.

El Tahir A, Satti GMH, Khalid SA 1999. Antiplasmodial activity of selected Sudanese medicinal plants with emphasis on Maytenus senegalensis (Lam.) Exell. $J$. Ethnopharmacol 64: 227-233.

Feng X, Gao Z, Li S, Jones SH, Hecht SM 2004. DNA polymerase, lyase inhibitors from Maytenus putterlickoides. J Nat Prod 67: 1744-1747.

Freire MO 1998. Estudo fitoquímico e psicofarmacológico das raízes de Maytenus obtusifolia Mart. (Celastraceae). Dissertação de Mestrado - Programa de Pós-Graduação em Produtos Naturais e Sintéticos Bioativos, Universidade Federal da Paraíba, João Pessoa.

Gessler MC, Tanner M, Chollet J, Nkunya MHH, Heinrich M 1995. Tanzanian medicinal-plants used traditionally for the treatment of malaria - in vivo antimalarial and in vitro cytotoxic activities. Phytother Res 9: 504508.

Gonzalez FG, Portela TY, Stipp EJ, Di Stasi LC 2001 Antiulcerogenic and analgesic effects of Maytenus aquifolium, Sorocea bomplandii and Zolernia ilicifolia. J. Ethnopharmacol 77: 41-47.

Iversen PO, Nicolaysen G 2003. Water-for life. Tidsskrift for den Norske Laegeforening 123: 3402-3405.

Jorge RM, Leite JPV, Oliveira AB, Tagliati CA 2004. Evaluation of antinociceptive, anti-inflammatory and antiulcerogenic activities of Maytenus ilicifolia. $J$ Ethnopharmacol 94: 93-100.

Kloucek P, Svobodova B, Polesny Z, Langrova I, Smrcek S, Kokoska L 2007. Antimicrobial activity of some medicinal barks used in Peruvian Amazon. $J$ Ethnopharmacol 111: 427-429.

Liu C, Crawford JM 2005. O Trato Gastrointestinal. In: Kumar, V.; Abbas, A. K.; Fausto, N. Robbins \& Cotram Patologia - Bases Patológicas das Doenças. 7 ed. Rio de Janeiro: Elsevier Editora Ltda, p.838-918. 
Lopes WB, Moroni FT, Brandeburgo MIH, Hamaguchi A 2002. Desenvolvimento de um método alternativo ao uso de animais de laboratório para avaliação da toxicidade de extratos vegetais. Revista Eletrônica Horizonte Científico 1: 1-11

Martins ER, Castro DM, Castellani DC, Dias JE 2003. Plantas Medicinais. 5. ed. Ver. Viçosa: UFV, p. 15-19.

Matu EN, van Staden J 2003. Antibacterial and antiinflammatory activities of some plants used for medicinal purposes in Kenya. $J$ Ethnopharmacol 87: 35-41.

Maity P, Biswas K, Roy S, Barnergee RK, Bandyopadhyay U 2003. Smoking and pathogenesis of gastroduodenal ulcer - recent mechanistic update. Mol Cell Biochem 253: 329-338.

Melo SF, Soares SF, Costa RF, Silva CR, Oliveira MB, Bezerra RJ, Caldeira-de-Araujo A, Bernardo-Filho M 2001. Effect of the Cymbopogon citrates, Maytenus ilicifolia and Baccharis genistelloides extracts against the stannous chloride oxidative damage in Escherichia coli. Mutat Res 496: 33-38.

Mizui T, Doteuchi M 1981. Effect of polyamines on acidified ethanol-induced gastric lesions in rats. Jap J Pharmacol 33: 939-945.

Otake T, Mori H, Morimoto M, Namba T, Otake T, Sutardjo S, Ueba N 1995. Screening of Indonesian plant extracts for anti-human immunodeficiency virus type 1 (HIV1) activity. Phytother Res 9: 6-10.

Parra AL, Yhebra RS, Sardiñas IG, Buela LI 2001. Comparative study of the assay of Artemia salina $\mathrm{L}$. and the estimate of the medium lethal dose $\left(\mathrm{LD}_{50}\right.$ value) in mice, to determine oral acute toxicity of plant extracts. Phytomedicine 8: 395-400.

Perez-Victoria JM, Tincusi BM, Jimenez IA, Bazzocchi IL, Gupta MP, Castanys S, Gamarro F, Ravelo AG 1999. New natural sesquiterpenes as modulators of daunomycin resistance in a multidrug-resistant Leishmania tropica line. J Med Chem 42: 43884393.

Raza M, Al-Shabanah OA, El-Hadiyah TM, Al-Majed AA 2002. Effect of prolonged vigabatrin treatment on hematological and biochemical parameters in plasma, liver and kidney of Swiss albino mice. Scientia Pharmaceutica 70: 135-145.

Santos VL, Costa VBM, Agra MF, Silva BA, Batista LM 2007. Pharmacological studies of ethanolic extracts of Maytenus rigida Mart (Celastraceae) in animal models. Rev Bras Farmacogn 17: 336-342.

Silva MS, Sousa DP, Medeiros VM, Folly MAB, Tavares JF, Barbosa-Filho JM 2008. Alkaloid, flavonoids, and pentacyclic triterpenoids of Maytenus obtusifolia Mart. Biochem Syst Ecol 36: 500-503.

Stevens PF, 2001. Angiosperm Phylogeny Website. Version 7. Available at: http://www.mobot.org/MOBOT/ research/APweb/. Access in May 2007.

Szelenyi I, Thiemer K 1978. Distention ulcer as a model for testing of drugs for ulcerogenic side effects. Arch Toxicol 41: 99-105.

Tarnawski, AS 2005. Cellular and molecular mechanisms of gastrointestinal ulcer healing. Digest Dis Sci 50: 2433.

Teo S, Stirling D, Thomas S, Hoberman A, Kiorpes A, Khetani V 2002. A 90-day oral gavage toxicity study of d- methylphenidate and d,l-methylphenidate in Sprague Dawley rats. Toxicology 179: 183-196.

Veiga-Junior VF 2008. Estudo do consumo de plantas medicinais na Região Centro-Norte do Estado do Rio de Janeiro: aceitação pelos profissionais de saúde e modo de uso pela população. Rev Bras Farmacogn 18: 308-313.

Vellosa JCR, Khalil NM, Formenton VAF, Ximenes VF, Fonseca LM, Furlan M, Brunetti IL, Oliveira OMMF 2006. Antioxidante activity of Maytenus ilicifolia root bark. Fitoterapia 77: 243-244.

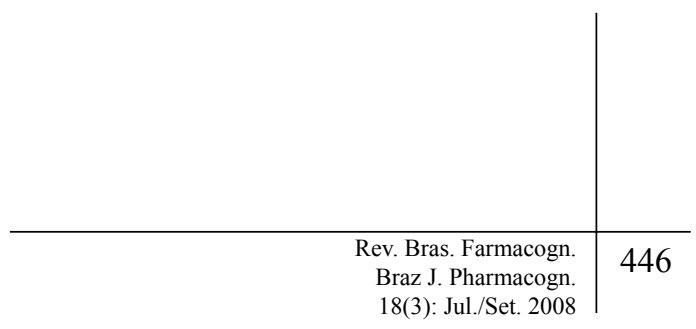

